\title{
THE RISE OF CHINA BETWEEN CULTURAL AND CIVILIZATIONAL RATIONALITIES: LESSONS FROM FOUR QING CASES
}

\section{Chih-Yu Shih}

National Taiwan University

E-mail cyshih@ntu.edu.tw

\section{Chihyun Chang}

Shanghai Jiao Tong University

E-mail chihyun@sjtu.edu.cn

The rise of China is a major feature of global politics at the beginning of the twenty-first century, and one that raises the question of how a rising China and global politics will adapt to each other. This study argues that historical cases are also useful in addressing this question. Four cases are compared: two during the reign of Emperor Xianfeng and another two under the rule of Emperor Guangxu. Emperor Xianfeng's view of China was that it possessed a unique culture that should be separated from alien forces, which he intuitively conceived as different, whereas Emperor Guangxu accepted exchanges with the West as a civilization and was willing to learn from them as a cultural resource. Despite this difference in their political perspectives, both emperors similarly faced constraints to their power in implementing their policies. Two cases are selected for each emperor to demonstrate how they acted differently from a cultural orientation of estrangement and exchange on one hand as well as a position of strength and weakness on the other. This comparative study provides insights into how China in the twenty-first century adapts to its expanding influence.

Keywords: Rise of China; Qing; War; civilizational politics; cultural memory

\section{INTRODUCTION: GLOBAL POLITICS VS. CHINA}

China's rise is a major feature of global politics at the beginning of the twenty-first century that raises many questions. In the process of moving from a position of relative weakness to a position of relative strength, how will a rising China and global politics adapt to each other? Will China's rise be a rational process or not? This article argues that in addition to current international relations theory, historical cases are also useful in answering these questions. Primarily, the article asks whether or not, and how, China is ready to learn from and adapt to global conditions and how a general frame of foreign policy motivations can evolve from a discussion on China. In the article, four cases are compared: two 
took place during Emperor Xianfeng's reign and another two under Emperor Guangxu. Emperor Xianfeng considered China as possessing a unique culture, which should be separated from alien forces, while Emperor Guangxu accepted exchanges with the West and was willing to learn from them. However, both emperors similarly faced constraints to their power in implementing their policies. We have selected two cases for each emperor to show how they acted differently from a position of strength and a position of weakness respectively. This comparative study provides hints as to how twenty-first century China will adapt to its expanding influence during its rise.

Some scholars suggest that China is capable of learning and will gradually merge into the world diplomatic order. ${ }^{\mathrm{I}}$ Others argue that China will retain its culturally unique approach to foreign policy. ${ }^{2}$ The following analysis tackles the question indirectly by proposing a theme of non-apparent rationality and relationship in order to bridge the two strings. Four cases from the Qing Dynasty will illustrate how Chinese intellectual and historical legacy can support both perspectives. These cases show that Chinese foreign policy (CFP) motivations are analytically comparable and generalizable and yet also distinctive in substance. CFP espouses non-apparent rationality, which refers to the pursuit of long-run security and stability achieved through consensual relationships. Theoretically as well as historically, as we will show, CFP contains two generalizable kinds of international relationships: a civilizational relationship to accommodate or acquire new ways of exchange and a cultural relationship to enforce or protect the perceived uniqueness of China. In order to provide a comprehensive analysis, this article also examines how these two relationships play out when China is weak.

Recently, Chinese scholars have also contributed cultural perspectives on China's foreign policy style. One perspective holds that the Chinese worldview is generally tolerant toward the coexistence of other nations and values. 3 This partly Daoism-inspired view welcomes spontaneous contact and mutual learning of all kinds. The other perspective asserts that China's past endorses a hierarchical order as a ready substitute for equal sovereignty. ${ }^{4}$ This view, which builds partly on the Chinese legalist tradition, alerts members to estranging forces outside of the hierarchical system. The two views diverge significantly on how they should treat other nations. However, it is necessary to point out that both views embrace no synchronic institutional arrangements or universal rules of conduct prescribed by globalization or International Relations (IR) theorists. Both views subscribe instead to some kind of long-term relationship. In addition to either learning from or aversion to alien influences, a third view mediates between them. This third view is partly Confucianism-inspired and maintains that reciprocal relationality is an essential element of the Chinese world order. At the same time, however, this view acknowledges the negotiability of the substance of the relationship. ${ }^{5}$ This last view attends to both inclusiveness

I For example, Carlson 2005; Johnston 2008.

2 For example, Jacques 2009; Kang 2007.

3 Zhao 2009; Zhao 2006.

4 Yan 20II; Paltiel 20II.

5 Qin 20II. 
and hierarchy. It remains alert for alien intervention on behalf of universal ruling that disrupts relational stability.

From the above-mentioned Chinese scholarly literature, three distinctive features stand out. First, the Chinese scholars display a strong temporal sensibility that favors long-term thinking embedded in a relational order as opposed to immediate accretion or protection of power and interest. Second, their relational sensibilities divert into two attitudes, with one stressing open-minded giving and taking, and the other self-centered conversion and exclusion. Third, as a result, the temporal and relational sensibilities constrain the use of CFP power to the effect that power is an instrument instead of a motivation. These three features in the contemporary literature are noticeable in the historical cases to be discussed below, indicating the importance of relational choice between the civilizational and the cultural relationships throughout. After all, this choice is a significant aspect of CFP that involves human judgment and transcends the typical power concerns in the anglophone IR. Therefore, the Chinese leaders' judgment on relational sensibility necessarily constitutes the answer to the practical question about how China will enter global governance.

\section{PURPOSE: THE CIVILIZATONAL VS. CULTURAL APPROACH}

Relational sensibility is always rational and long-term. It is rational because it simplifies the policymaking process by dodging the uncertainty involved in the calculation of the national interest in the short run and concentrating on the benefit presumably accrued from the stability brought by the relational security in the longer run. However, this benefit is usually not apparent at the present time, so relational sensibility may appear to lack rationality in the short run. The long-term rationality in the pursuit of relational security resembles the repeated play of the prisoners' dilemma, in which an actor encourages the other side to cooperate by yielding, seemingly irrationally, in the first few rounds so that the other side might learn to appreciate the benefit of switching to a strategy of cooperation. The benefits in the long run should include security, peace, independence, and order, etc. These benefits are the same as the short-term calculus of national interest, except that relational sensibilities enable one to be patient. The concerns for the relationality thus prompt China to compromise, even with a weaker opponent, in the short run to signal willingness to maintain an existing relationship and to confront, even with a stronger opponent, to demonstrate the determination to destroy a relationship that has already decayed.

Moving beyond the Chinese literature, the generalizable theory of cultural memory can inform the division between the civilizational and the cultural relationship. For this article, cultural memory refers to the collectively established orientation toward present difference in value, identity, and world order. We accept the cultural memory division between society and the individual on the one hand, and between material resources and those of the mind on the other. ${ }^{6}$ Accordingly, cultural memory depends on both the shared meanings 
among members of a society and the symbolic and material resources accessible to each of them in order to convey the shared meanings.7 Both shared meanings and the resources to support them are necessary for cultural memory to form and evolve. Nonetheless, there is implicitly a theoretical differentiation. The perception of shared meanings gives rise to the identity of the we-group. It immediately and intuitively sensitizes the difference between the in- and out-group. On the other hand, cultural resources are instrumental, diffusional, and undetermined. Accordingly, we can divide CFP's take on relational sensibility into the "cultural relationship" aimed at protecting or enforcing perceived Chinese uniqueness, ${ }^{8}$ which intuitively spawns a policy preference for estrangement; and the "civilizational relationship" that shows fluidity, hybridity, ambiguity, and open-endedness, so that China can accommodate or acquire new ways of interaction. ${ }^{9}$ By enlisting the theory of cultural memory, CFP is a comparative case instead of a unique one.

The cultural relationship approach reflects the idea that the Chinese stick with one another because they have inherited a shared system of meaning. As such, Chinese culture will continue to prosper in the future. To become Chinese, one grows up and lives amongst other Chinese, and internalizes one's inherited, shared consciousness. Arguably, it is rather unlikely for an alien to become Chinese under the cultural approach embedded in shared memory whereby Chinese people and Chinese culture mutually define each other. When the CFP makers take the cultural relationship approach, the purpose is to maintain the perception of Chinese uniqueness by resisting foreign influences or enforcing the Chinese way during interaction with foreign nations. The uniqueness of China is conceived of as the intuitive incurring of cultural memory; those who fail to comprehend its cultural meanings are excluded. The cultural purpose to protect or enforce one's own style will lead to tense relationships with other nations. Suspicion toward difference is intuitive and attempts to remain estranged reflect a long-term motivation.

The same encountering that is threatening under the cultural relationship, if taking place in a learning context, would incur an entirely opposite CFP orientation. This would be the civilizational relationship, which may accommodate to or even acquire foreign resources through the adoption of selected values and their associated practices, including institutions, technology, language, cuisine, religion, style, and so on. The civilizational approach is thus premised upon flexible kinship, whether real or imagined. With civilizational openness, the CFP purpose is to interact by means of either preaching or learning so that cultural resources can be more extensively shared. The civilizational purpose of CFP leads to more relaxed international relationships, as the incurring or re-incurring of shared cultural resources is conducive to mingling and openness. In the same vein, as opposed to the cultural relationship approach, the reciprocal exchange is a cultural ideal that defines the long-term goal of CFP despite the seeming loss of national interests at the present time.

And yet, the same purpose can yield different short-run orientations in accordance with the perceived relative power of China. Perceived relative strength at the moment of

7 Erll 2008, p. 7.

8 For a discussion on the cultural approach, see Gries 2004; Shih I990.

9 For example, Callahan 2004. 
policymaking, in combination with cultural CFP, leads to enforcement policies - a condition we call "Empire." In contrast, perceived weakness in China's relative power under the cultural relationship produces policies of resistance and protection, resulting in the condition we call the "Great Wall." On the other hand, in the perception of a relatively powerful position, a CFP that adopts the civilizational approach which exchanges and shares cultural resources will sustain ambiguity in relationships and exercise patience over unresolved issues, i.e. a condition of "Tianxia." The same approach is also ready to actively acquire new practices, institutions, and kinship in the condition of "Sinification," when perceiving a relatively powerless position. ${ }^{\text {Io }}$ In sum, the cultural memory approach, together with the realist calculus of relative power, yields four generalizable possibilities, each of which sprouts a culturally sensitive orientation in the Chinese context.

\section{Empire}

A familiar intuitional memory in the Chinese worldview is to divide the world into the civilized and the barbarian. The Confucian saying_yan yi xia zhi fang 嚴夷夏之防 (adhering to the defense of Chinese from barbarians) - reminds one of the cultural self-centrism in Chinese political tradition. The Great Wall symbolizes the estranging state of mind. When the CFP makers perceive that China is stronger, China enforces the ritual that ensures its role at the top of the hierarchy through either reward or punishment. As a Chinese growing up and living in a foreign land or in ethnic groups living on the social and territorial margins, one is faced with two choices: to believe that one is like-Chinese to adopt voluntary cultural conversion, or to believe that one deserves no attention due to the lack of cultural preparation. Visiting barbarians are required to adopt Chinese practices before receiving preferential treatment. Punishment is applied to visiting barbarians who are perceived to violate Chinese customs or values.

History has witnessed the practice of granting much more in return to a neighbor or visitor who pays tribute. This obvious lack of rationality has led to the establishment of an order in which the Chinese self-identity of being at the center of the world would not be challenged, while at the same time this culturally intuitive order legitimizes extraction and unlimited access to resources in times of crisis, i.e. the non-apparent and incalculable benefits of hedging. (Table I)

\section{The Great Wall}

A China perceived as weak is intuitively in danger of intrusion by barbarians. China's distinctive order is in such jeopardy that resistance and exclusion is called for. The predicament is that China's weakness does not allow confident resistance, to the effect that confrontation could be merely symbolic rather than substantial. Symbolic confrontation could occur in many modes. For example, it could be a well-planned sequence of quick reactions and disengagement. It could also be the execution of internal opponents who advise compromise. ${ }^{\text {II }}$ Other possibilities include a claim of future revenge, a desperate

Io For more discussion, see Van Ness I985; Callahan 20I0; Shih I990; Nathan and Ross I998. 
Table r. Chinese foreign policy rationality

\begin{tabular}{|c|c|c|}
\hline $\begin{array}{l}\text { CFP Purpose in long run } \\
\text { Relative Power in short run }\end{array}$ & Cultural & Civilizational \\
\hline High & Empire & Tianxia \\
\hline Low & Great Wall & Sinicization \\
\hline
\end{tabular}

but useless act of self-sacrifice in order to shame the arriving barbarians, a strong act of selfsacrifice aimed at intimidating the arriving barbarians, or over-reaction to perceived, but unintended, disrespect, with the result of overthrowing already established consensus or reconciliation.

The purpose of resistance is to make a nationalist statement to the intruding barbarians that weakness does not keep China from asserting uniqueness. How much benefit these often apparently ineffective responses to the perceived as well as real dangers can accrue is dubious since it is neither measurable nor guaranteed. Nevertheless, the quest for acknowledged uniqueness could prevail over a concession policy even though concession would be sure to reduce the apparent loss. In any case, adherence to such a symbolic distinction reinforces the losing side's self-awareness and thus preserves the drive for restoration in the long run.

\section{Tianxia}

The drive for assimilation or exclusion of barbarians decreases if the attitudinal orientation of CFP makers is toward learning, sharing, or preaching. China is allegedly at the top of an open hierarchy. CFP makers would want to accommodate and even promote diversity and divergence in the periphery by acquiescing to their petty maneuvers as if contradiction is natural and intrinsic to the human world, which a selfless Chinese leadership exclusively represents. To some extent, contradiction is even desired, for such contradiction or alienation from Chinese values indirectly attests to unimposing Chinese leadership. The major motivation is to demonstrate China's all-embracing capacity to accommodate all possibilities in the spirit of a Confucian wish, hence all-under-heaven, i.e. Tianxia.

What would appear to be concessional policy in accordance with apparent national interest is a conscious choice for the sake of harmony or the transcendence of confrontation. This civilized attitude ensures that China would never be in anyone else's way so that Chinese leadership always appears welcome. At least, it would be unnecessary to substitute an alternative for Chinese leadership, which preaches without any demand for synchronization.

\section{Sinification}

Nationalist resistance is not the only CFP solution to the crisis of intrusion or containment by the West. Facing unfriendly international relations under the circumstance of perceived weakness, another CFP option is to cut across the mutually estranged national identities. Reconnection or reactivated existing connections between China and its opponents should 
be a practiced way often seen before in Chinese history. One popular method of reconnection in Chinese history is to acquire a mutual identity through marriage or voluntary hostages. In addition to social reconnection that obscures national boundaries in order for China to escape from being the target of containment, there is civilizational reconnection. This option is not available unless the CFP makers willingly acquire and share international means and norms. Sinification in this sense refers to ways to make things Chinese easier for foreigners and things foreign easier for Chinese to understand, practice, or even internalize.

The civilizational CFP does not rely on inaccessible cultural memory to define China. Now that China is so aware of its limitations that it is prepared to learn from other civilizations and comply with their practices, the CFP could appear to be losing jurisdiction, control, or dignity when barbarian advisors are practically admired or barbarian standards are strictly observed. Nevertheless, the civilizational purpose is to catch up with the major powers according to their criteria and methods.

\section{A Methodological Note on Cultural Memory}

All groups to a certain degree adopt the cultural approach, and the cultural approach reinforces and reproduces in-group consciousness. Social identity theory has demonstrated that group consciousness generates discriminative intuition that favors group members even where the group is artificial and temporary. ${ }^{\mathrm{I2}}$ The same self-protective mechanism applies both to China and elsewhere in general. However, despite the same two-on-two cultural mechanism, the cultural memory of different groups, each embedded in its own geo-cultural trajectory, inevitably motivates foreign policy differently. For example, a weaker nation adopting the cultural approach may resort to resistance to external influences or social segregation of certain alien components, depending on its perceived relative power, as opposed to the aforementioned, distinctively Chinese notions of Great Wall or Sinification. In other words, the four categories of cultural memory are universal while the substance of each category is geo-culturally distinctive.

That said, one's overall designation of national purpose still requires one to make judgments on whether or not one should resort to exclusion or mingling in a specific context. Each being inclined to a certain disposition, no group is homogeneous, hence the inevitable agency of its policymakers. On the one hand, they show in their choosing, changing, and restoring, a purpose. As cultural memory can fail to prevail in a foreign policy event as well as in a domestic challenge, such deconstruction of the previous evaluative intuition may compel policymakers to rely on alternative memories. This would engender a change in evaluative intuition so as to reorient their policy. On the other hand, the agency of policymakers also shows when adopting a certain style of fulfilling their purposes. For example, the civilizational approach necessarily ensures that a decision on how cultural learning, sharing, or preaching should take place and with whom it is legitimate (e.g. a neighbor, a long-term rival, a globalizer, or a stranger, etc.). In short, intuitive congruence on the civilizational approach does not guarantee policymakers will reach a consensus on actual policy. 
The cultural memory that provides evaluative intuition is rational in a peculiar sense. It is rational not because an objective calculus leads to an accurate cost-benefit scale, but because the purposes that motivate and orient policy loom accordingly. The purpose tells what relationship policymakers should strive for and accordingly targets a longterm goal, usually defined in terms of security and stability. However, the purpose has no control over the result. It is nearly impossible to predict how long it will take to satisfy the purpose or whether it is possible at all to reify the purpose. Therefore, the purpose is essentially a non-apparent kind of national interest. In the short run, disposition toward fulfilling the purpose gives rise to the appearance of seeming to lack rationality. As a result, to what extent one should strive to abide by the purpose is in itself a matter of cultural belief and personal style. In any case, the cultural memory explains how a seemingly failing policy can nevertheless appear intellectually reasonable in the light of a certain purpose.

The cultural and civilizational purposes, together with the switch between them and the style of fulfilling them, make the cultural memory a proper framework to compare foreign policy motivation in general and show the cultural mechanisms that explain how and where rising China can or cannot learn to adapt in particular.

\section{CASE STUDIES: SHORT VS. LONG-TERM}

The following four cases use Emperor Xianfeng as a representative example of the cultural approach and Emperor Guangxu as one of the civilizational approach. These cases, arranged chronologically, are like cases in Western historians' eyes, because they reflect China's systematic resistance to Western progressive influences. In reality, the nineteenth-century CFP decision makers acted differently in these four cases. The issue at hand in the former two cases was that the Chinese side intuitively refused to abide by the treaty rights of the barbarian to interact with the Chinese. The latter two cases reflect a shared concessional purpose and a similar strategy of intermingling to accommodate challenges or obscure differences in order to restore or establish a relationship. The cases do not imply that the two emperors were consistent elsewhere or their court officials were in agreement with them. This article tries to explicate these four cases in terms of the CFP quest for non-apparent national/rational interests qua relational propriety. Culture and rationality are not opposite. On the one hand, cultural memory reproduces intuitively relational sensibilities that leave their mark centuries later to sustain a presently weakened identity; on the other, sharing of cultural resources deliberately softens China as an object of offense.

\section{Empire: The Arrow Incident during the First War of the Anglo-French Alliance}

A highly self-regarding China, combined with a cultural CFP, would be rigid and adamant toward barbarians. The outbreak of the Arrow War in I858, out of the motive to challenge the lofty position claimed by recalcitrant barbarians, led to the most serious hostile SinoWestern engagement of the nineteenth century. Owing to this local war in Canton, the British and French alliance entered Beijing in I860 and razed the Summer Palace in 
Peking to the ground. This was the first time in the history of the Qing Empire that the capital city had been taken by foreigners and the first time the emperor had abandoned his ministers and palace there. Given the gravity of these events, there seems to have been an absolute lack of rationality on behalf of China's foreign policymakers.

Both the Chinese and the Western accounts treat Liang-Kwang Viceroy Yeh Ming-chen (I809-I859) as a critical figure in these events. Yeh "belonged to the last generation of Chinese imperial civil servants to grow up in a world on which Western influence had not yet begun to impinge." 3 Contemporary and current Western scholars find it difficult to rationalize Yeh's seemingly ridiculous behavior. First, Yeh mobilized local militia to resist the British from entering Canton, as was permitted under the treaty. He rejected requests by foreign representatives to meet, with the single exception of agreeing to see Sir John Bowring (I792-I872, Governor-General of Hong Kong I854-I859) in a trade house, and with the sole purpose of humiliating Bowring, who emphatically refused the invitation. When his troops first arrested some of the crew from a Chinese-owned and Chinese-manned vessel called the Arrow and then pulled down the British Ensign, ${ }^{\mathrm{I} 4}$ the Acting Consul of Britain, Henry Parkes (I808-I88I), understood this as yet another violation of the Treaty of Nanking. ${ }^{15}$ He ordered an attack. However, Yeh's militia was able to hold back the enemy, and forced them into retreat. In retaliation, the triumphant Yeh went on to cut the supplies to the British in Hong Kong, forcing them all to put out to sea for other supplies.

However, financial support for the militia, which Yeh solicited from those who used to profit from foreign trade, ceased due to the closing of business. When the British came back with reinforcements, Yeh tried in vain to agitate the people of Canton, in substitution for the militia, to rise up in their own defense. He was only able to prepare himself for capture at his desk by means of having his own supply of food as he declined any offer of food from Britain. After he was transferred to Calcutta, his own supplies of food ran out and he was to end his life in a seventeen-day hunger strike. Judging from the aforesaid short description, Yeh was an outdated traditional hardliner and lacked a sound knowledge of foreign affairs. His actions can be better understood, however, if cultural CFP is applied to this case.

In the eyes of Yeh, the barbarians and the Chinese could not interact via written arrangement. He regarded the ship in question as being domestic because flying a British Ensign could not alter the fact that the Arrow was Chinese-owned and Chinesemanned. He similarly relied on a Chinese-manned city to deny entry to the British. Before he received Yeh's official reply, Parkes had already sent a dispatch to Sir John Bowring and Commander George Elliot (I784-I863) requesting naval support. ${ }^{16}$ However, Yeh did not understand why Bowring used the Arrow incident to threaten him in demanding that the British enter the city of Canton, as for him these two matters were totally unconnected. The only meaningful strand connecting both events was that the

Hudson I976, p. Xv.

I4 Hurd I967, p. I2.

I5 Article II, Treaty of Nanking, I842. Statistical Department of the Inspectorate General of Customs, I9I7, p. 352 .

I6 FO 228.2I3, Parkes to Bowring and Elliot Despatch No. I50, 8 October I 856. 
Chinese and the barbarians had to remain separated. In the eyes of Bowring and Parkes, these two issues were, on the contrary, the same thing because they were both regulated by the Treaty of Nanking.

It was very unlikely that Yeh and Bowring and Parkes could have reached any consensus as separation and exchange were two quite opposite purposes. A war seemed inevitable. Both sides took the "empire" approach to coping with the other. Therefore, from either the British perspective, which could not accept any negotiation, ${ }^{17}$ or the Chinese perspective, war was inevitable. The war was conducive to a typical cultural CFP in Yeh's resolute position that demonstrated, consolidated, and capitalized on the presumed cultural difference:

[Yeh] restrained his troops from even firing on the enemy in defense when the latter tried to capture forts on the outskirts of the city, so as to let the Cantonese see with their own eyes that the British were the aggressors. By so doing, he hoped to achieve two aims: first, that the people of Canton would be provoked and would stand up to the enemy, who he thought, would realize that they had by mistake antagonized the people and would retreat; second, if the British nevertheless insisted on a military solution, the alienated people of Canton would fully back up their government in the war effort. ${ }^{\text {I8 }}$

A villain in most British foreign documents, Yeh's determination to revoke the agreed entry of the barbarians practically made the wall of Canton into a mini Great Wall, which he had mistakenly thought he could have defended with the support of Cantonese anti-foreignism, and even sought to bolster this sentiment. ${ }^{\text {I9 }}$

Imagine that had Yeh had the level of power that he had thought he had, would his approach have been not unlike Deng Xiaoping's decision in 1982-widely considered shrewd by Deng's contemporaries - to force from Margaret Thatcher the return of Hong Kong? Yeh's lofty style of waiting for the enemy to fire the first shot has also been the standard CFP in the twentieth-first century as reiterated in the contemporary national defense principle of "tit for tat" (or ren bu fan wo wo bu fan ren, ren ruo fan wo wo bi fan ren 人不犯我我不犯人, 人若犯我我必犯人). At most, Yeh could be faulted for miscalculating the British strength, but this was by no means lacking in rationality. In fact, his purpose and his strategy were consistent. To say the least, Yeh's stylistic use of anti-foreign sentiment was the first of its kind in Chinese modern history. Note that anti-foreign sentiment has continued to gird the quest for national unity to some extent in the twenty-first century.

\section{The Great Wall: The Second War of the Anglo-French Alliance}

The Arrow War and the subsequent First War of the Anglo-French Alliance ought to have cleansed the myth that China had the upper hand. That said, an intuitively confrontational attitude could nevertheless persist even with foreseeable losses, as long as the emperor

\footnotetext{
I7 Wong I998.

I8 Wong I976, p. I7I.

I9

Wong I976, p. I67.
} 
adopted the cultural approach. This was the case indeed after the signing of the Treaty of Tianjin in 1858 . The Treaty temporarily ended the war, but not the cultural memory of the intuitively estranged West, even though China obviously could no longer sustain it.

The atmosphere of the time that surrounded the Xianfeng Emperor (I83I-I86I) continued to be one in which the Chinese and barbarians had to be kept separate. This compelled him to adopt an uncompromising cultural CFP despite the fact that the weakness of China that he had witnessed in person during the Opium War would have suggested that he opt instead for making concessions. The emperor continued to believe that the requested stationing of delegations of barbarians in Beijing was not acceptable, nor was Beijing the place to carry out their intended exchange of rectifications. ${ }^{20}$ As history unfolded, two incidents virtually bound the emperor to a confrontational approach. One was the destruction of British warships at Taku, and the other was the detention of Henry Parkes. During and after these incidents, the cultural rationality to assert a righteous order prevailed over the immediate battle assessment. This, as we will now demonstrate, was a deliberate choice of the emperor's rather than ignorance arising out of insanity.

The first defeat suffered by China at the Taku garrison in I 858 again disclosed the weakness of the gate of the Celestial Court. The Xianfeng emperor instructed Mongolian cavalry general Sengge Linchin (I8II-I865) to enhance the defenses at the Taku forts and dispatched thousands of soldiers there. ${ }^{2 I}$ Sengge Linchin's response was adamant and enthusiastic, ultimately resulting in an irrevocable event. He first reported to the emperor that if the representatives insisted on entering Peking, "We would be forced to deter them with our military power. The only solution will be to encourage the soldiers and bombard their ships in order to express the Celestial Court's justice and cease their demonic aggression."22

When they anchored at the Taku garrison in June 1859, the British and French plenipotentiaries did not expect any engagement. As none of them had made any military preparations, the British lost 89 lives with an additional 345 wounded from bombardments. ${ }^{23}$ The loss and retreat inflamed the feud between China and Britain. In the fury of unexpected defeat and the insult of diplomatic failure, the Anglo-French forces came back with full preparations for war. The battle only lasted for seven days. ${ }^{24}$ The gate of the Celestial Court was opened by force and they all thought the war was over. ${ }^{25}$

The bombardment in June I859 was a political statement on the proper Chinese-barbarian relationship rather than on the execution of war policy. The emperor had no such policy. The following event would appear even more absurd. After the third battle of Taku, Sengge Linchin retreated to Tungchow, which was 8 kilometers away from the Forbidden City. ${ }^{26}$ While Prince Yi Tsai Yuen (I8I9-I86I) and Lord Elgin (James Bruce,

Emperor Xianfeng to Grand Councillors, 25 March I859, XF YWSM, vol. IV, p. I329.

Emperor Xianfeng to Grand Councillors, 9 March I859, XF YWSM, vol. IV, p. I304.

Sengge Linchin to Emperor Xianfeng, 2 April I859, XF YWSM, vol. IV, p. I337.

Hurd I967, p. I83.

Hurd I967, pp. 2I4-I5.

Hurd I967, p. 2 I6.

Sengge Linchin to Emperor Xianfeng, 24 August I80, XF YWSM, vol. VI, p. 2 I38. 
I8I I-I863) were communicating with each other, Parkes showed up again, accompanied by Thomas Wade (I8I8-I895). In the eyes of the Westerners, "Parkes and Wade came back thoroughly satisfied, and completely deceived." 27 The reason why the British thought they were deceived is that Parkes was taken into custody by Sengge Linchin. ${ }^{28}$ The emperor had not intended the episode, however. In the first instance it happened because Sengge Linchin personally wanted to hold Parkes responsible for all the problems in I858 and afterwards. $^{29}$ The actual order of arrest was given by Prince Yi when his suggestions were declined outright by Parkes. ${ }^{30}$ When informed of the arrest, Prince Yi stated that "... the Anglo-French forces have no strategist and the Chinese troops should be able to defeat them easily." ${ }^{\text {I }}$ The capture of Parkes meant this particular war could not be ended easily.

The Xianfeng emperor was unsure if he should release Parkes because of the heightened tensions at his court. After all, the emperor was ultimately accountable for yan yi xia zhi fang. Could he show less concern over the celestial order than the dangers of war? In fact, for millennia, Confucianism had cherished the virtue of sacrifice more than that of life when facing defeat. The virtue of sacrifice presumably ensured that national revival would eventually succeed and the barbarians would be defeated through the voluntary sacrifice of generation after generation. No emperor should refuse to set such an example in the face of the approaching barbarians. Based on this rationale, his court officials had him in something of a quandary with regard to Parkes's case. In fact, the emperor appeared more and more determined as the chances of holding off the barbarians from intrusion into the Forbidden City decreased. He then declared that he would give up peace as long as the approaching barbarians insisted on handing over the treaty to him in person.

The possibility of resuming cultural separation and punishing the barbarians was so attractive that almost all court ministers suggested the emperor execute Parkes as they considered him to be a prisoner of war. These ministers proposed hundreds of useless tactics to him, in effect only repeating the principle of yan yi xia zhi fang. For instance, a prosecutor of Shanxi Province argued that "our soldiers should attack the foreign troops in the evening because they cannot see in the evening and they sleep like pigs. Our cavalries are superior to their cavalries because foreigners do not know how to ride horses. We should set up traps because foreigners cannot bend their knees...."32

In this xenophobic atmosphere, the emperor was actually considering escaping. For an immediate solution, he could have either allowed the Alliance to come to Beijing or run away without further fighting. In reality, he chose neither. Apparently, he was resigned to fighting a hopeless war. This was quite unlike Yeh Minchen, who once believed that he stood a good chance. Nevertheless, this again suggests that the purpose was more important than the concern for security in determining the immediate CFP. The emperor

27 Lane-Poole I90I, p. 232.

28 Sengge Linchin to Emperor Xianfeng, I8 September I86o, XF YWSM, vol. VII, p. 2322.

29 Loch I900, p. 98.

30 Prince Yi to Emperor Xianfeng, i7 September I860, XF YWSM, vol. VII, p. 23 I 9.

Emperor Xianfeng to Grand Councillors, I7 September I860, XF YWSM, vol. VII, p. 232 I. 
was seemingly more culpable than Yeh since he could have anticipated the result better than Yeh would have done. The result was actually worse than he had anticipated. In fact, the signing of the Treaty of Peking in I86o resulted in a heavier cost than otherwise would have been incurred without confrontation - the Summer Palace was razed and the emperor abandoned the imperial capital and never returned. But most importantly, China had to admit that the Chinese side's reckless actions were the cause of this war. ${ }^{33}$

In I865, the Inspector-General of the Imperial Maritime Customs Service of China, Robert Hart (I835-I9II), submitted his “A Bystander's Viewpoints” to the Zongli Yamen in 1865 . He felt that confrontation was irrational, especially for an obviously weaker party. 34

However, to be in accord with Hart could not seem rational from the cultural CFP point of view. All these calculable infringements that had already happened would not be considered infringements by the barbarians in the future if China were to expediently accept them in order to stop the Alliance forces. What if the emperor had understood that the war would ensue regardless of whether the request was met with or not? The best guess is that he would not have changed his policy, because he actually knew that he had no chance. This would be similar to realizing that the war was inevitable unless he were to comply. Such compliance would be tantamount to inviting other barbarian powers to follow suit. The emperor was also conscious of the shame that a treaty signed under pressure could create for him. The cultural purpose is embedded in the assumption that China and the barbarians had to remain estranged in order for the Xianfeng emperor to continue to recreate that estrangement. Unfortunately for them, the unavailing relational security left both the astounded Yeh Ming-chen and, subsequently, his clear-headed emperor completely disempowered in what seemed to be a state of insanity.

All this ought to suggest to coming generations that China succumbed to the treaty rights in I860 not because it was in agreement, but because the barbarians imposed them upon China regardless of China's disapproval. The deliberate choice of the emperor to suffer defeat and immensely exacerbate the cost of war to China, among other similar events, left the Chinese in future generations a nationalist consciousness of wanting to restore relational propriety. Xianfeng apparently did not specifically anticipate the actual return of Chinese nationalism in another century. His deliberation could only come from his intuitive compliance with the cultural belief that eventually his choice would benefit China. Once the calculation of national interests falls on the imagined horizon of an unlimited future, any cost-benefit analysis would appear myopic, granted that in the immediate event the emperor's choice could mean disaster. That is why the absolute separation of the barbarians from the emperor, which could have been worth nothing at the time, was worth everything in the long run. Needless to say, Xianfeng, upon his adamant insistence on separation, could never have been seeking to guarantee the emerging China dream in the twenty-first century. His long-term rationality, albeit intellectually acceptable, was at best a cultural calculus that could only lessen his sense of shame felt at the time. 


\section{Tianxia: Concession of the Ryukyu Islands}

The relational security embedded in a nominal hierarchy and indicated by the tribunal ritual shared by all relevant parties is essential to the graceful pose of Qing China at the center of all-under-heaven. However, any disturbance could destroy China's presumably graceful reign because if China were unable to control it, the rest of the world could fall into anarchical self-protection. When possible, China ought to try to appease a disturbed regional order in the hope that its nominal superiority could be maintained. Therefore, maintaining relational security may result in ambiguities or concessions in the short run so that a confrontational situation in which China's graceful reign is in jeopardy can be controlled. The thrust of the Tianxia worldview is precisely to demonstrate accommodation rather than asserting distinction. The Qing court's maneuvering of cultural resources to delay Japan's annexation of Ryukyu for almost two decades illustrated a style featuring ambiguity, patience, and inconsistency and thus the less intense approach that is typical of the Tianxia CFP.

In December I876, the Ryukyu king sent his brother-in-law Kōchi Chōjō (I843-I89i) to Fujian province, China to ask for the Qing court's help. ${ }^{35}$ Chōjō submitted a proposal and asked the Min-Zhe (Fujian and Zhejiang) Viceroy to forward this to the Qing court, stating that Japan would not allow Ryukyu to carry out the tribute rituals to China. Ryukyu's tribute was a sensitive issue at the time because the Qing court, although rendered less secure under the consecutive blows of foreign invasion, could nonetheless maintain a posture as the center of the world in Ryukyu's tribute relationship with the Qing Empire.

The Empress Dowager Cixi (I835-I908) realized the complexity of the Ryukyu case upon hearing China's Japan Minister He Ruzhang's (I838-I89I) investigation into the situation. ${ }^{36}$ He reported that the reason why Ryukyu was ordered to stop carrying out the tribute rituals to China was that Japan planned to put Ryukyu under its county system. Of course, a Japanese county should neither have diplomatic relations with nor tribute obligations to China. The reason that Chōjō did not simply report the detention of his king by Japan was that he suspected, rightly, that China would have an interest in getting involved in direct confrontation with Japan to save his king, if not also for the sake of restoring a nominal relationship.

Cixi did not want the already tense Sino-Japanese relations to deteriorate further, because China and Japan had likewise had diplomatic conflicts in Taiwan in I874. The Ryukyu issue was more sensitive. Since Ryukyu had been China's feudatory for more than a hundred years, the Qing court was supposed to protect Ryukyu from Japan's annexation. But China would gain very little if it were able to successfully protect Ryukyu, as Ryukyu was relatively small. Japan was by no means the main challenge facing the court. The only issue remaining was that the Qing court really needed to perform like a responsible metropolitan state and protect its feudatory.

Minister He Ruzhang proposed three solutions, namely I) China should send its navy to Ryukyu and force it to continue the tribute rituals; 2) China should prepare a joint attack plan against Japan with Ryukyu; or 3) China should ask the foreign powers' diplomatic 
representatives in Japan to mediate the dispute. 37 All these would have reduced China to no more than another calculative power equal to Japan, which would have put them in an awkward position. After all, what China ought to have needed was no more than an excuse for inaction so that it remained on top, but in no one else's way, as no selfless leadership would ever do.

Regent Prince Gong (I 822-I898) asked former US President Ulysses Grant (I822-I 885) to mediate the dispute. In the eyes of Prince Gong, the former US president was, of course, more influential than the foreign powers' diplomatic representatives in Japan because Japan was "opened" by the US navy in the I860s. ${ }^{38}$ Grant was received by the Meiji emperor and met the Minister of Public Affairs Itō, and then designed a compromise. The northern islands of Ryukyu would be ceded to Japan and put under Kyushu's jurisdiction, and the southern islands of Ryukyu would be ceded to China and put under Taiwan's jurisdiction. The main island, Okinawa, would be returned to the king of Ryukyu and Japan would release the king and his son to re-establish the Ryukyu kingdom. ${ }^{39}$

This solution saved face for China, Japan, and Ryukyu, although Ryukyu obviously suffered from Japan's partition. China was ready to accept this compromise. However, Japan's representative Takezoe Shinichiro (I842-I9I7) stated that China could take the southern islands but that Japan would take the northern islands and Okinawa. The Qing court was obliged to decline this proposal as it did not serve the purpose of nominally continuing the Ryukyu kingdom. ${ }^{\circ}$ Then the Qing court started to discuss how to finalize this matter, and both a military expedition and economic embargo were discussed, but neither appeared proper nor decent.4I

The reason why the Qing court was unwilling to take a firm policy toward Japan was to avoid the image of losing control if Japan was not going to change its policy. This stood in contrast to Xianfeng's decision, which was to demonstrate disapproval despite having already lost control. Xianfeng faced a stronger opponent than Cixi, so Cixi had a much better chance of maintaining China's reign over all-under-heaven, at least militarily. However, forcing a policy on Japan to restore the Ryukyu kingdom could backfire if not immediately successful. This was different from her husband's situation in which surrendering would have improperly given the impression of approval. For Cixi, not showing strong disapproval could in effect camouflage the fact that China might have already lost the Ryukyu kingdom, which it actually cared nothing about except for the concern over relational propriety.

Cixi's most trustworthy Governors-General and Viceroys started to discuss whether China should ally with Russia or Japan. While the choice between Russia and Japan was strategic, the debate was premised upon China's nominal relationship with Ryukyu in terms of how to legitimately leave the Ryukyu issue in perpetual stalemate. The debate

37 Gong, Io April I879, Qingji Waijiao Shiliao, vol. XV: I I.

38 Gong, 7 July 1879, Qingji Waijiao Shiliao, vol. XVI: I9.

39 Gong, 29 September I879, Qingji Waijiao Shiliao, vol. XVI: 2 I.

40 Gong, 26 July I880, Qingji Waijiao Shiliao, vol. 21: 25.

4I Chen 2012 (pp. 97-IOO) discusses Li Hongzhang's anxiety toward any engagement with the presumably subordinate Japan over trivial values. 
was whether or not it made sense to try achieving relationality with Japan so that the Ryukyu issue could be set aside for the more important relationship to develop. Ambiguity on the Ryukyu issue could be justified if it enabled a stable relationship with Japan. The first court member who took an obvious stance was Zhang Zhidong (I837I909). Zhang argued as if Ryukyu were no longer the real issue:

China should not be afraid of Japan but be aware of Russia's threat ... The Ryukyu Kingdom is very unlikely to resist Japan's invasion so China should consolidate China's diplomatic relations by improving our trade terms with Japan. If Sino-Japan relations are strong enough, Japan will not lend Russia its military harbor. Thus, we should suspend the decision on the Ryukyu issue and lure Japan with better trade terms in order to persuade Japan not to ally with Russia. ${ }^{2}$

This argument was challenged by Chih-Li Viceroy Li Hongzhang, who argued likewise as if Ryukyu was no longer the real issue:

Even if China were able to ally with Japan with pretty words and heavy bribery, China can still expect Japan to betray us and look after its own interests once China and Russia are in conflict ... Now Japan discerns its own conditions and can only agree to lend Russia its military harbor in Nagasaki and sell it coal and rice. It is not within China's reach to release Japan from its thirst for profits from Russia or fear of its strength ... Conceding to Japan would not help us resist Russia but would make us simultaneously lose to Japan and Russia. In comparison, how about we concede to Russia and deter Japan with our Russian connection? ${ }^{43}$

But Nanjing Viceroy Liu Kunyi (I830-I902) had a different opinion. Liu straightforwardly indicated that Ryukyu should not be an issue at all:

Japan has a two-thousand-year history so it is very unlikely that China can occupy Japan forever. If China sends troops to Japan, there is no guarantee that China can defeat Japan. If Japan is defeated, what we can do? The Ryukyu islands are much closer to Japan. Can we hold them forever? If we cannot, do we want to send troops again and take the islands back?44

Together, these three officials reduced the Ryukyu case to an embarrassing condition, to the effect that even if China ought to do something, there was nothing that could be suitably done. Disliking this either/or choice between Russia and Japan that would have placed China against either the one or the other, Cixi decided to move beyond alliance building. 
She had no confidence in any sort of diplomatic alliance whatsoever. Seen in the larger strategic picture, which illuminated the impossibility of the Ryukyu issue, she set it aside and focused on strengthening China's naval power. A civilizational CFP of accommodation under which China stood in the way of no one else's apparent interests was Cixi's preferred choice. Consequently, both displeasure toward Japan and readiness to accede to Japan's unfriendly encroachment could coexist. This became and remained the thrust of CFP until the twenty-first century.

Note that neither Zhang nor Li favored a strong policy on the Ryukyu issue since no strong policy could guarantee the restoration of the disturbed order without risking failing a test of China's doubtful reign over all-under-heaven. They both looked for a longer-term policy that could wishfully either lure or discipline Japan back to China's world order, which should by all means transcend mutually excluded sovereign domains. China's seeming lack of determination on the Ryukyu issue thus arose out of a deliberate calculus that reflected a civilizational wish for China to be big enough to accommodate all those petty maneuvers on the periphery and for China to actually achieve its high status, providing a sufficient period of time to demonstrate its inclusiveness via an enhanced trade relationship. At its minimum, inaction covered the possible incoming loss of a workable relationship and bought time for restoration in the long run. In reality, this imagined perception that Japan could still find a place in the Chinese world order resulted in China's eventually falling prey to all major powers almost twenty years later during the Sino-Japanese war in I 894 .

In comparison, whereas a similar encroachment took place in France's military action in both An Nan (Vietnam) and Taiwan, the Qing actually reacted strongly by engaging France on the battlefield, indicating that the Tianxia approach was not consistently applied under Guangxu. Nevertheless, this was perhaps the first major war that China did not apparently lose. To preserve this unusual parity with a European power on the battlefield, China ironically yielded suzerainty of An Nan to France. As long as China's disapproval of the French encroachment was successfully demonstrated, the emperor moved quickly to avoid escalation by making a territorial concession, in order to establish the pretense that territorial possession, in An Nan and Ryukyu alike, was only a minor issue in allunder-heaven. Under the Tianxia approach, to whom, how much, and in what style China should yield is at its discretion. Culturally, yielding was neither imperative nor necessarily culpable.

\section{Sinification: The Appointment of Hart}

Reconnection, which is aimed at establishing a reciprocal relationship via the incurring of shared cultural resources that can obscure China as a distinctive object of exploitation, can be typically sewn together through transnational characters. Foreign advisors have played critical roles over centuries in China. Take the aforementioned Sir Robert Hart, InspectorGeneral (IG) of the Inspectorate General of Customs during the Qing Dynasty, who personified the transnational nature of the institution of Customs administration. He started his career in China in I854 as an assistant interpreter in Britain's Ningbo Consulate. After nine years, he was appointed IG by Prince Gong and held this post until he passed away in I9II. In practice, he single-handedly established the modern customs system for 
China. It is not an exaggeration to say that Hart sinicized the institution of international commerce for China to the extent that he practically demonstrated that such an efficient and incorrupt institution could adapt itself to the Chinese conditions for the Chinese to use. He was the "most powerful Westerner in China for decades." 45

However, his appointment met with surprise among Western observers as well as skepticism from Chinese intellectuals for an entire century. Why would a barbarian be allowed such power over vital national interests, especially when Hart endeavored to comment on China's internal issues in his "Bystander's View"? Zhejiang Governor-General Ma Xinyi (I82I-I870) was among the most skeptical as he argued:

Hart suggested that the foreign powers could help China train troops, but he actually planned to distribute foreign troops in China; the foreign powers could help to manufacture machines, but his plot was to put foreigners in China; and that trains and rails are the best way to deliver these around China ... If we sanction his proposal, foreigners could control the court and sabotage China. ${ }^{46}$

Regardless of the fact that he was British, Robert Hart was undoubtedly appropriate for the IG post as he had been involved in the acquisition of China's first steamer fleet, namely the Flotilla project in I86I,47 although Hart had not yet been appointed IG. This project turned out to be a failure, but the Ryukyu issue reminded the Qing government of the importance of naval power for China. After eighteen years of peace, China was interested in more powerful battleships rather than flotillas. However, when Hart showed the provincial leaders "big-gun gunboats" while being considered as Chief Inspector of Coastal Guards, Jiangsu Governor-General Shen Baozhen (I820-I879) said that the big-gun gunboats "cannot steam against a head-wind or sea and cannot go fast with wind and tide in favourfurther, that they cannot work their guns except in smooth water, and that they are not fit for deep water fighting." 48

Shen's concerns seemed to reflect very little knowledge of Western technologies, but in fact Shen was famous for his open-minded attitude toward learning from the West. The reason why Shen was so lukewarm had to do with Robert Hart himself. Xue Fucheng (1838-I894) explained their shared concerns as follows: "Robert Hart is insidious and manipulative. Although he enjoys a high-ranking post and a high salary, Hart still protects Westerners' interests.” Xue criticized:

Hart already controls the customs service and collects tariff tax. If he is put in charge of coastal defenses, China's navy and revenues will be completely controlled by Hart ... A few years will pass and the government will not be able to superintend Hart anymore ... If the government can offer the same power to

45 Spence I969, p. I28.

46 Ma Xinyi, 27 November I866, in Jindai zhongguo dui xifang ji lieqian renshi ziliao huibian, vol. 2.2, pp. 687-92.

47 For the Flotilla project, see Gerson I972, pp. I5I-76.

48 Hart to Campbell, 26I, Z/8, I I October I879, IG in Peking vol. I, p. 306. 
the Northern and Southern Ministers and transfer the tariff income levied by Hart to the Ministers, what else can the Chinese not achieve?49

Hart's attempt to control the Chinese navy thus was stopped by Shen and Xue, and the person behind the scenes was undoubtedly Li. Shen and Xue had reasonable grounds for opposition to Hart's appointment. Note that Horatio Nelson Lay, Hart's predecessor as IG, had likewise sought direct authority over the Qing's military affairs for the sake of administrative centralization. Their suspicion, albeit reasonable, resulted in the destruction of the Southern fleet by the French navy in I884, and of the Northern one by the Japanese navy in I895. Even to this day China's coastal defenses have not been rebuilt.

The subsequent Boxer Rebellion sent Cixi and Emperor Guangxu (I87I-I908) into refuge, heading for Xi'an on I5 August I900, only a few hours before the Eight-Nation's armies overran the Forbidden City. The City was occupied by the Alliance for over a month, and a hefty indemnity was exacted from the Imperial palace. Two consecutive defeats testified to the failure of the previous four decades and the wisdom of Hart's critics. In reality, however, a belated rationale for Hart's appointment re-emerged exactly at the moment of the empress and the emperor's "Hunt to the West" (Xishou), which took almost four months, only for them to realize that an intimidating negotiation awaited them.

Hart, Prince Qing, and Li Hongzhang together manufactured the signing of the Boxer Protocol, reaffirming Fairbank's account of the post-I86o practice of a "Manchu-ChineseWestern 'synarchy." 50 Li Hongzhang was aware of his own limitations, so he suggested that "Hart is the best candidate as consultant for negotiations with the powers but he is also a victim of the Boxer rebellion. The Throne has to bestow a significant honor upon him in order to convince him to go." ${ }^{51}$ Hart's reaction enacted his role in reconnecting China into a larger relationship:

The situation now is extremely critical. The IG has been given so much honor by the Court so he does not have the heart to watch the situation deteriorating with folded arms..$^{2}$

Cixi immediately consented and decreed that “... Her Majesty gladly appointed Prince Qing and the IG as plenipotentiaries for negotiations with the foreign powers.” 53

Hart's task was to convince the foreign powers not to destroy the Manchu empire, as they needed to reach a consensus-how to punish China seriously enough to deter it from planning another xenophobic mass movement. Hart began by publishing essays in The Times. He first analyzed for his readers why the Boxer Rebellion was still possible after four decades of self-strengthening. He then disputed the idea of partitioning China

49 Xue 1879, pp. 53-55 (ro August 1879).

50 Fairbank I975, p. 465.

5 I Li Hongzhang to Cixi, 6 August I900, Xixun Dashiji, vol. I, pp. 31-33; quoted from Wang and Wang I934, pp. $402 \mathrm{I}-22$.

52 Natong to Cixi, 26 August I9oo, Xixun Dashiji, vol. I, p. ıо; Qingji Waijiao Shiliao, vol. IV, p. 40 Io.

53 Cixi to Hart, 27 August I9oo, Xixun Dashiji, vol. I, p. I6; Qingji Waijiao Shiliao, vol. IV, p. 40 I3. 
or installing a new dynasty. ${ }^{54}$ His conclusion appealed to the importance of reconnecting China to the rest of the world:

The only practical solution, in the interest of law and order and a speedy restoration of the tranquility that makes life and commercial relations safe and profitable, is first of all to leave the present dynasty where it is and as it is, and let the people of China deal with it themselves when they feel its mandate has expired. 55

Hart had conferred on him the title of Taizi Shaobao (Guardian of the Heir-Apparent) in the aftermath; ${ }^{6}$ he was the only Westerner this title was ever bestowed on. Hart was obviously flattered by this gesture, which was in his eyes made him equal to the leading reformers of the time Zhang Zhidong and Yuan Shikai (I859-I9I6), hence his comment: "the Chinese say [of] a big honor." 57 Not only did Hart make the Imperial Customs Service suitable for Chinese norms, but he himself also enjoyed being sinified. Synarchy was the quintessential illustration of civilizational CFP for a perceived weak China in need of acquiring Western knowledge.

Seven years after the signing of the Boxer Protocol, Robert Hart retired, but the Qing court insisted that he remained the IG, which meant he could return to China and direct the Chinese Maritime Customs Service whenever he liked. Interestingly, The Times commented on his retirement that "if in the conduct of diplomatic negotiations he sometimes chose to consider that primarily he owed a duty to his Chinese associates, we are not now disposed to criticise him on that account." ${ }^{58}$ He witnessed both the confusions and struggles in CFP and also endeavored to direct it back onto the right track.

\title{
China Not Aware of Its Responsibilities?
}

Robert Hart's analysis in I865 concluded:

\begin{abstract}
Although Westerners were happy that the resulting treaties could settle everything, local authorities usually violated the articles' contents. Westerners then suspected that this was because their higher ranking officials were not aware of these treaties, but the higher ranking officials did not understand what the Westerners thought. Thus, military engagements occurred again, and this caused that all sorts of treaties would be sent to Beijing.59
\end{abstract}

54 Hart igor, p. 84.

55 Hart igor, p. 99.

56 Cixi Edict, I I December ı9or, Xixun Dashiji, vol. XI, p. 27; Qingji Waijiao Shiliao, vol. IV, p. 4283.

57 Hart to Campbell, Z/9i4, I5 December I90i, Chen and Han I990, p. 603.

58 The Times, 23 April 1908.

59 Hart I880/2007 I668, pp. I672-73. 
Indeed, in the twenty-first century, treaties and various kinds of global legal responsibilities continue to rock the CFP's position against intervention in certain target states. This reminds us of the fact that China's "higher ranking officials were not aware" of these responsibilities.

Putting cultural memory in a nutshell, the Chinese political and cultural preference for stable long-term relationships has led to a different mode of rational thinking. The Chinese national interest calculus is centered on the preservation of intuitively imperative relationships in order to minimize future uncertainty. To lend credibility to its pursuit of stable relationships, China is ready to compromise on such apparent national interests as territory, power, energy, or economic gain. For the sake of credibility, China is likewise prepared to resort to violence from time to time when necessary, in order to demonstrate its determination to restore what it perceives to be a proper relationship. Neither of these behaviors appears rational from any realist's point of view.

Having agreed to participate in global governance, China is painstakingly attempting to stabilize those relationships that it cannot unilaterally control. Global governance requires major powers to cooperate in making rules and to synchronize national practices everywhere. Inevitably interventionist politics ensue. China, in contrast, only lukewarmly participates in the rule-making and alienates herself from interventionist enforcement. Nevertheless, China's approach to global governance is not consistent with any quest for apparent national interests. Rather, there have been consistent and intuitively correct pledges on the necessity of controlling disturbance in accordance with "the development of the bilateral relations from a strategic and long-term perspective" in all those statements cosigned by a good number of "strategic partners," including a power as great as the United States, as similar as India, as remote as Mexico, as suspicious as Vietnam, as divided as Iraq, as fast-changing as Myanmar, as bitter as Japan, as old-fashioned as the UK, as proud as France, as neutral as Singapore, as ambivalent as Mongolia, and as understanding as Russia. These bilateral sensibilities transcend the quest for universal rules essential to global governance or the resolution of dispute abiding by a unilateral perspective of national interest. They favor instead patience over any immediate solution.

It is in this regard that China's choice between civilizational and cultural approaches echoes the same challenge facing the Qing court. It is a challenge between the openended exchange of cultural resources to become embracive and sociable and the instinct of adhering to the shared meaning among the Chinese population to remain distinctive and with lofty ideals. Such a choice challenges all nations all the time, so it is not in essence Chinese. Nevertheless, in the short run, the relative power in one's possession constrains the choice. China's rise today forms a significant contrast to the decline of the Qing dynasty; indeed, making both Tianxia and empire a more credible choice than either Sinification or Great Wall. Table 2 juxtaposes the non-apparent and yet long-term and rational interests of the four cases against the national interest calculus that ignores temporality. This non-apparent rationality emerges into four CFP practices under the four conditions that the crossing of the two different purposes and the two different levels of relative power produces. The last row of Table 2 lays out the CFP performance in response to the arrival of global governance. 
Table 2. Rational and non-apparent national interests of the four cases

\begin{tabular}{|c|c|c|c|c|}
\hline & $\begin{array}{c}\text { The First War of } \\
\text { Anglo-French } \\
\text { Alliance }\end{array}$ & $\begin{array}{c}\text { The Second War of } \\
\text { Anglo-French } \\
\text { Alliance }\end{array}$ & $\begin{array}{c}\text { Japan's Subjugation } \\
\text { of the Ryukyu } \\
\text { Kingdom }\end{array}$ & $\begin{array}{c}\text { Negotiation with } \\
\text { the Eight-Nation } \\
\text { Alliance }\end{array}$ \\
\hline $\begin{array}{l}\text { Rational } \\
\text { Interest }\end{array}$ & National security & $\begin{array}{l}\text { Peace and } \\
\text { independence }\end{array}$ & $\begin{array}{l}\text { Power balance } \\
\text { and order }\end{array}$ & Regime security \\
\hline Rational policy & $\begin{array}{l}\text { Abiding by the } \\
\text { treaty rights of } \\
\text { foreigners to enter } \\
\text { Canton }\end{array}$ & $\begin{array}{l}\text { Conceding to the } \\
\text { rights of entry to } \\
\text { Peking }\end{array}$ & $\begin{array}{l}\text { Confronting Japan } \\
\text { through } \\
\text { diplomatic and } \\
\text { military means }\end{array}$ & $\begin{array}{l}\text { Trusting only } \\
\text { the Chinese } \\
\text { nationals }\end{array}$ \\
\hline CFP Condition & Empire & Great Wall & Tianxia & Sinicization \\
\hline CFP Purpose & $\begin{array}{l}\text { Conversion or } \\
\text { exclusion }\end{array}$ & $\begin{array}{l}\text { Resistance or } \\
\text { disengagement }\end{array}$ & $\begin{array}{l}\text { Concession or } \\
\text { patience }\end{array}$ & $\begin{array}{l}\text { Compliance or } \\
\text { relationship }\end{array}$ \\
\hline CFP Practice & War & Escape & Inaction & Synarchy \\
\hline $\begin{array}{c}\text { Non-Apparent } \\
\text { Rationality }\end{array}$ & $\begin{array}{l}\text { Promote anti- } \\
\text { foreignism }\end{array}$ & $\begin{array}{l}\text { Disapprove } \\
\text { exchange }\end{array}$ & $\begin{array}{l}\text { Disguise } \\
\text { Disharmony }\end{array}$ & $\begin{array}{l}\text { Obscure } \\
\text { boundary }\end{array}$ \\
\hline $\begin{array}{l}\text { Non-Apparent } \\
\text { Interest } \\
\end{array}$ & Control & Restoration & Status quo & Survival \\
\hline $\begin{array}{c}\text { Contemporary } \\
\text { disposition }\end{array}$ & $\begin{array}{l}\text { Distinction } \\
\text { consciousness }\end{array}$ & $\begin{array}{l}\text { Independence } \\
\text { consciousness }\end{array}$ & $\begin{array}{l}\text { Harmony } \\
\text { consciousness }\end{array}$ & $\begin{array}{l}\text { Openness } \\
\text { consciousness }\end{array}$ \\
\hline $\begin{array}{l}\text { Global } \\
\text { governance }\end{array}$ & China Model & Autarky & Non-intervention & Self-governance \\
\hline
\end{tabular}

The critical attitude regarding global governance is determined by the choice of relationship. Neither cultural nor civilizational relationships respond directly to global governance, which stresses rules of international relations and synchronization of domestic governance. The civilizational relationship does not abhor global governance. Rather, under civilizational sensibilities, global governance proceeds upon voluntary learning and practice at each site, with China at times readily conceding on the delay, revision, and even rejection of the international rules via the target of global intervention. At most, China would succumb to negotiated intervention which does not require conversion of local values and institutions or changes in the local regime. The local regime, including China, should be left autonomous to determine how, or how not, to openmindedly acquire and implement global values and institutions. Global governance is tantamount to simultaneous self-governance. In contrast, the cultural relationship engrains the morale for the promotion of the China model and the China Dream when China is relatively strong, and yet resorts to separatist autarky when China is relatively weak.

The above comparative study of the two periods and four cases has demonstrated that diplomatic history proceeds upon the undecidability of the long-term purpose and the calculable short-term power possessed. Whichever purpose China chooses, it is not helpful in enhancing Chinese officials' awareness of international responsibilities. Even under the civilization relationship, China prefers to allow room for the local regime to enact the rule of global governance according to its own interpretation and need. However, only if China is in possession of power with a cultural sensibility toward intuitive difference 
will it challenge global governance with an alternative option of the China model. And, the same can be said about any other nation's global policy. How the China model asserts itself and what it affects are, however, subjects of another study.

\section{REFERENCES}

Adelman and Shih I993

Adelman, Jonathan and Chih-yu Shih. Symbolic War: The Chinese Use of Force, 1840-1980. Taipei: Institution of International Relations, I993.

Assmann 2006

Assmann, Aleida. "Memory, Individual and Collective." In The Oxford Handbook of Contextual Political Analysis, ed. E. Goodin and C. Tilly, pp. 2 I0-24. Oxford: Oxford University Press, 2006.

Callahan 20 I0

Callahan, William. China: The Pessoptimist Nation. Oxford: Oxford University Press, 2010.

Callahan 2004

Callahan, William. Contingent States: Greater China and Transnational Relations. Minneapolis: University of Minnesota Press, 2004.

Carlson 2005

Carlson, Allen. Unifying China, Integrating with the World: Securing Chinese Sovereignty in the Reform Era. Stanford: Stanford University Press, 2005.

Chen 20I2

Chen, Ching-Chang. “The 'Loss' of Ryukyu Revisited: China's No Use of Compellence in the Sino-Japanese Border Dispute, I877-I880.” Afrasia Symposium Series Studies on Multicultural Societies I (2012), pp. 87-I05.

Chen and Han I990

Chen, Xiafei and Han Rongfang, eds. Archives of China's Imperial Maritime Customs: Confidential Correspondence between Robert Hart and James Duncan Campbell, 1874-1907. Beijing: Foreign Languages Press Beijing, I990.

Ding I934

Ding Richang 丁日昌. "Mindu hejing deng zou liuqiu qianshi rugong riben gengzu gingzhi Banlizhe fu shangyu 閩督何璟等奏琉球遣使入貢日本梗阻請旨辦理摺附上諭” (Fujian-Zhejiang Viceroy He Jing and his staff reported that Ryukyu sent the representatives for tribute rituals to China but Japan stopped them), 24 June I877, Qingji Waijiao Shiliao 清季外交史料 (Diplomatic Materials of the Late Qing), eds. Wang Yanwei 王彥威 and Wang Liang 王亮. Peiping, I934.

Erll 20I I

Erll, Astrid. Memory in Culture. London: Palgrave Macmillan, 20 I I.

Erll 2008

Erll, Astrid. "Cultural Memory Studies: An Introduction.” In Cultural Memory Studies: An International and Interdisciplinary Handbook, ed. A. Erll and A. Nunning, pp. I-I7. Berlin: de Gruyter, 2008.

Fairbank I975

Fairbank, John King, Katherine Frost Bruner, and Elizabeth Macleod Matheson, eds. The I.G. in Peking: Letters of Robert Hart, Chinese Maritime Customs, I868-I907, Cambridge, MA: The Belknap Press of Harvard University Press, I975.

Gerson 1972

Gerson, J. Horatio Nelson Lay and Sino-British relations, I854-I864. Cambridge, MA: Harvard University Press, I 972.

Gong

Gong (Prince) 恭親王. “Zongshu zou yifu he ruchang hanshu riben zugeng liuqiu rugong yian xiangji zhuaoban zhe 總署奏議覆何如璋函述日本阻梗琉球入貢一案相機酌辦〈摺” (Zongli Yamen instructed He Ruzhang how to deal with Japan and Ryukyu). Qingji Waijiao Shiliao 清季外交史料 I5 (Io April I879), p. II; “Zongshu zou meiguo qian zongtong hancheng zai riben shangban qiushi zhe 總署奏美國前總統函稱在日本商辦球事 摺” (Zongli Yamen reports that former US President is discussing the Ryukyu issue in Japan now). Qingji Waijiao Shiliao 26 (29 September I879), p. 2 I; "Zongshu zou meiguo qian zongtong zai riben tiaochu liuqiushi yiu banfa zhe 總署奏美國前總統在日本調處琉球事擬有辦法摺” (Zongli Yamen reports that former US President knows how to solve the Ryukyu issue in Japan). Qingji Waijiao Shiliao 26 (7 July I879), p. I9. "Zongshu zou riben feimie liuqin yian quanguo qianzong nijia tiaoting shiyi zhongbian qingjian dayuan shangban zhe 總署奏日本廢滅琉球一案全國前總擬加調停事已中變請减大員商辦摺” (Zongli Yamen reports 
that the situation that Japan annexed Ryukyu has changed so China should send high-ranking official to intercede on this issue). Qingji Waijiao Shiliao 2 I (26 July I880), p. 25.

Gries 2004

Gries, Peter. China's New Nationalism: Pride, Politics and Diplomacy. Berkeley: University of California Press, 2004. Hart I90 I

Hart, Robert. These from the Land of Sinim: Essays on the Chinese Questions. London: Chapman \& Hall, I90I. Hart I $880 / 2007$

Hart, Robert. “Juwai Pangguan Lun’ (Bystander’s Viewpoint), Tongzhichao Choban Yiwu Shimo 同治朝籌辦夷務 始末” (The Complete Account of the Management of Barbaric Affairs during the Tongzhi Reign). Peking: I880, reprinted Beijing: The Chinese Bookstore, 2007.

Hudson 1976

Hudson, G. F. "Foreword.” J. Y. Wong, Yeh Ming-chen: Viceroy of Liang Kuang (1852-I858). Cambridge: Cambridge University Press, I976.

Hurd 1967

Hurd, D. The Arrow War: An Anglo-Chinese Confusion, I856-1860. London: Collins, I967.

Jacques 2009

Jacques, Martin. When China Rules the World: The End of the Western World and the Birth of a New Global Order. New York: Penguin, 2009.

Johnston 2008

Johnston, Iain. Social States: China in International Institutions, I980-2000. Princeton, NJ: Princeton University Press, 2008.

Kang 2007

Kang, David. China Rising: Peace, Power and Order in East Asia. New York: Columbia University Press, 2007.

Lane-Poole I9or

Lane-Poole, S. Sir Harry Parkes in China. London: Methuen \& Co., I90 I.

Li I 880

Li Hongzhang 李鴻章. "Zhidu li hongzhang zou riben yijie liuqiuan qianshe gaiyue zheyi huanyun zhe 直督李 鴻章奏日本議結琉球案率涉改約暫宜緩允摺” (Zhili Viceroy Li Hongzhang reports that Japan attempts to change the trade agreement with China in order to wants to finalize the Ryukyu issue but China has to reconsider Japan's terms). Qingj Waijiao Shiliao 清季外交史料 24 (November I I, I880), p. 3.

Liu 1880

Liu Kunyi 劉坤一. “Jiangdu liu kunyi zou liuqiuan yisujie riyue yishenzhong tuwei zhe 江督劉坤一奏琉球案 宜速結日約宜慎重圖維摺” (Nanjing Viceroy Liu Kunyi reports that the Ryukyu should be ended immediately and China should be very careful when it signs agreement with Japan). Qingji Waijiao Shiliao 清季外交史料 24 (November 30, I880), pp. I5-I6.

Loch I 900

Loch, H. Personal Narrative of Occurrences during Lord Elgin's Second Embassy to China in I860. London: John Murray, I900.

Ma I866

Ma Xinyi 馬新貽. “Fengchen yangren chengdi juwai pangguan lu xinyi lunlue zhi yongyi bingchen ziqiang zhice 奉承洋人稱帝局外旁觀錄心意論略之用意並陳自強之策” (Hart’s Purpose of the Bystander’s View and How to Self-Strengthen). Jindai zhongguo dui xifang ji lieqiang renshi ziliao huibian 近代中國對西方及列強認 識資料彙編 2:2 (November 27, I866), pp. 687-92.

Nathan and Ross 1998

Nathan, Andrew and Robert Ross. The Great Wall and the Empty Fortress: China's Search for Security. New York: W. W. Norton, I998.

Oldmeadow and Fiske 2010

Oldmeadow, Julian A. and Susan T. Fiske. "Social Status and the Pursuit of Positive Social Identity: Systematic Domains of Intergroup Differentiation and Discrimination for High- and Low- Status Groups.” Group Processes and Intergroup Relations I3:4 (2010), pp. 425-44.

Paltiel 20II

Paltiel, Jeremy. "Constructing Global Order with Chinese Characteristics: Yan Xuetong and the Pre-Qin Response to International Anarchy.” Chinese Journal of International Politics 4:4 (20I I), pp. 375-403.

Qin 20II

Qin, Yaqin. "Rule, Rules, and Relations: Towards a Synthetic Approach to Governance." Chinese Journal of International Politics 4: 2 (20II), pp I I7-45. 
Qingshilu

Qingshilu 清實錄 (The Qing Emperors' Daily Records).

Shih 1990

Shih, Chih-yu. The Spirit of Chinese Foreign Policy: A Psychocultural View. London: Macmillan, I990.

Spence 1969

Spence, Jonathan. To Chang China: Western Advisers in China. New York: Little, Brown and Company, I969.

Statistical Department I9I7

Statistical Department of the Inspectorate General of Customs. Treaties, Conventions, Etc., between China and Foreign States I, 2nd edition. Shanghai: Statistical Department of the Inspectorate General of Customs, I9I7.

Stephan and Stephan 1985

Stephan, Walter G. and Cookie White Stephan. "Intergroup Anxiety.” Journal of Social Issues 4I:3 (I985), pp. I57-75.

Tongzhi Yiwu Shimo 2007

Tongzhi Yiwu Shimo 同治夷務始末. Beijing: Zhonghua shuju, 2007.

Van Ness 1985

Van Ness, Peter. “Civilizer States: America and China in the Modern World.” Unpublished paper. Denver, 1985.

Wang and Wang I987

Wang Yanwei 王彥威 and Wang Liang 王亮, eds. Qingji Waijiao Shiliao 清季外交史料 (Diplomatic Materials of the Late Qing). Beijing: Shumu Wenxiang Chubanshe, I987 (Peiping: 1934).

Wong 1998

Wong, John Y. Deadly Dreams: Opium and the Arrow War (I856-I860) in China. Cambridge: Cambridge University Press, I 1998.

Wong 1976

Wong, John Y. Yeh Ming-chen: Viceroy of Liang Kuang (I852-I858). Cambridge: Cambridge University Press, I976.

Xianfeng Yiwu Shimo

Xianfeng Yiwu Shimo (XF YWSM) 咸豐夷務始末 (The Complete Account of the Management of Barbaric Affairs during the Xianfeng Reign). Peking, I850, reprinted Beijing: Zhonghua shuju, I979.

Xixun Dashiji

Xixun Dashiji 西巡大事記 (The Chronicle of the Travel to the West) reprinted Beijing: Shumu Wenxian Chubanshe, 1987.

Xue 1879

Xue Fucheng 薛福成. “Shang li boxiang lun hede buyi zongsi haifang shu 上李伯相論赫德不宜總司海防書” (Why Robert Hart should not be put in charge of coastal defence), Yong'an wenbian 庸庵文編 2 (Io August I879), pp. 53-55.

Yan $201 \mathrm{I}$

Yan, Xuetong. Ancient Chinese Thought and Modern Chinese Power, eds. Daniel Bell and Zhe Sun, trans. Edmund Ryden. Princeton: Princeton University Press, 20 II.

Zhang I 880

Zhang Zhidong 張之洞. "Zuoshizi zhang zhidong zou Liuqiuan yishen huanji zhe fu shangyu 左庶子張之洞奏 琉球案宜審緩急摺附上諭” (Zhang Zhidong reports that the Ryukyu case should be prioritized). Qingji Waijiao Shiliao 清季外交史料 24 (November 3, I880), pp. I-3.

Zhao 2009

Zhao, Tingyang. "A Political World Philosophy in Terms of All-Under-Heaven (Tian-xia).” Diogenes 56:I (February 2009), pp. 5-I8.

Zhao 2006

Zhao, Tingyang. "Rethinking Empire from a Chinese Concept 'All-under-Heaven' (Tian-xia)." Social Identities I2:I (January 2006), pp. 29-4I. 